\title{
Correction to: Subcutaneous lipomas: A minimally invasive method for resection of subcutaneous lipomas preserving retaining ligaments
}

\author{
Akio Sakamoto $^{1} \cdot$ Takeshi Okamoto $^{1} \cdot$ Shuichi Matsuda ${ }^{1}$
}

Published online: 21 March 2018

(C) The Author(s) 2018

\section{Correction to: Eur J Plast Surg https://doi.org/10.1007/s00238-017-1328-5}

The article Subcutaneous lipomas: A minimally invasive method for resection of subcutaneous lipomas preserving retaining ligaments, written by Akio Sakamoto, Takeshi Okamoto, Shuichi Matsuda, was originally published electronically on the publisher's internet portal (currently SpringerLink) on 9 June 2017 without open access.

With the author(s)' decision to opt for Open Choice the copyright of the article changed on 19 March 2018 to (c) The Author(s) 2018 and the article is forthwith distributed under the terms of the Creative Commons Attribution 4.0 International License (http://creativecommons.org/licenses/by/4.0/), which permits use, duplication, adaptation, distribution and reproduction in any medium or format, as long as you give appropriate credit to the original author(s) and the source, provide a link to the Creative Commons license and indicate if changes were made.

Open Access This article is distributed under the terms of the Creative Commons Attribution 4.0 International License (http://creativecommons. org/licenses/by/4.0/), which permits unrestricted use, distribution, and reproduction in any medium, provided you give appropriate credit to the original author(s) and the source, provide a link to the Creative Commons license, and indicate if changes were made.

The online version of the original article can be found at https://doi.org/ $10.1007 / \mathrm{s} 00238-017-1328-5$

Akio Sakamoto

akiosaka@kuhp.kyoto-u.ac.jp

1 Department of Orthopaedic Surgery, Graduate School of Medicine, Kyoto University, Shogoin, Kawahara-cho 54, Sakyo-ku,

Kyoto 606-8507, Japan 